\title{
Private Label Motivators and Product Category Association: An Empirical Study
}

\author{
Ritu Srivastava*
}

\begin{abstract}
Private labels are important contributors in a retail strategy, especially when the industry starts maturing and competition starts intensifying. While modern trade penetration in India is still low, the proportionate private label growth is much higher owing to a new generation of shoppers that is open to trying out new products and brands. It is thus important to understand the private label motivators in India and also to understand the role of product category in the private label decision. This particular study aims at these two objectives in the Indian context. The findings of the study indicate that product category does have an intervening role in the customer's private label purchase decision. The implications need to be assessed and incorporated in the private label strategy of the retailers.
\end{abstract}

Keywords: Private labels, Retail, India, Product category, Customer motivations, Customer choice

\section{Background}

Private labels are great assets for retail firms, as they help attract customers, build loyalty and generate large sales margins. Across the globe as retailers become more sophisticated and competitive,

\footnotetext{
Assistant Professor, MDI, Gurgaon, India; ritu.srivastava@mdi.ac.in
} 
the role of private labels in their stores changes from being a price fighter to that of a value added marketing differentiator. Though private labels have evolved worldwide from being cheap substitutes for manufacturers' brands to strong contenders for them over the years, their role in the Indian market at present is limited. Many Indian retail firms have launched their private labels, but several of them have not been very successful.

Private labels like Food Bazaar's Fresh-n-Pure, Reliance fresh's Select and TATA-Trent's Westside are very popular among Indian consumers. Indian consumers have begun to acknowledge the modern form of retailing as a better option for purchasing their requirements due to the shopping convenience that it provides them on many counts. This has led to manufacturers queuing up for the prominent stocking of their brands on the retail-storeshelves so as to influence consumer's purchase decisions effectively (Kumar, Jawahar and David, 2013). The competition to a manufacturers' brand, of late, comes not only in the form of popularity of other manufacturer brands, but also in the form of predominant presence of private labels in these retail outlets. Retailers are more likely to gain an increase in their category profits by introducing private labels in product categories which have a lot of manufacturers' brands.

As private label brands account for an increasing percentage of a consumer's shopping basket, several scholars and marketers have attempted to understand and explain consumer behaviour towards private label brands. Extant academic research on private label brands has attempted to profile the private label brand consumers on a variety of psychographic variables. These include studies focusing on price and price consciousness, quality perceptions, brand and store loyalty, deal proneness, search and risk assessment and product involvement. The growing importance of private labels has given rise to a number of research works in recent years worldwide and India as well. These researches are related to private labels with reference to investigating the consumer, retailer and market factors for their success. Broadly categorized, researches are related to investigating motivations and benefits of private labels for retailers, consumer segmentation studies, studies of consumer perceptions, attitudes and behaviour, retailer 
positioning of private labels and the strategic responses of national brand manufacturers (Richardsoii, Dick and Jain, 1994, Scattone, 1997, Burton, Donald, Richard and Judith, 1998, Šeštokaitè, 2010, Fischer, Shukla, Banerjee and Adidam, 2013, Cramer and Hoyer, 2014)

In India, a few research papers on private labels have been published in recent years. These research works include study by Gala, Ramchandra and Patil, 2013 on consumer attitude towards private label and national brand and their behaviour towards various retail outlets and Kirana stores available in the Sangli district, Maharashtra India. The study concluded that the customers see private label as a local product which is not been considered same as the national brand. The majority of respondents prefer both national and private label as compared to individual specific brand, but has changed along with change in demographic profile. Product wise preferences shows that, majority customers prefer national brands for purchasing electronic, luxury, sanitary and clothing items whereas they prefer private label for food and other miscellaneous items. Private labels purchase is influenced by positive world of mouth. On other hand, poor quality is a major reason for people do not prefer to buy private label products. The major reasons of purchasing private labels are quality followed by price and then availability in the retail outlet. Joshua, Selvakumar and Varadharajan, 2013 did a similar study in Coimbatore, India and revealed that preference pattern changes with respect to demographic profile of respondents for private label brand and national brand. They examined three categories of private labels, namely food and non food FMCG, apparel and consumer durables and found that freshness is the most important factor that contributes the sales growth of private labels. Respondents prefer excellent packaging towards brand and value for money towards private labels. It is inferred that quality and price of national brand products are high when compared to private label products, packaging of national brand products are attractive when compared to the private label products, risk of buying national brand products are less risk when compared to the private label products and brand image of buying national brand products are high when compare to the private label products. Senthilvel Kumar, David and Jawahar, 2013 also performed study in 
Coimbatore, India to understand perception and intention of consumer while purchasing private labels. The study revealed that the buyers of private labels could be classified into three and two clusters respectively. The respondent's age and income did not influence their perception and intention, but their gender did.

\section{Research Objectives}

This study on private labels assumes importance in the light of the fact that very few Indian-market-specific findings are presently available for understanding the buying behaviour related to private labels in India. This research study has two objectives;

- To identify the primary motivators for private label purchases across product categories in India

- To see if there is any association between private label motivators and product categories.

\section{Research Outcome}

- This exploratory study empirically investigates the principle reasons for which people buy private labels in India;

- Explores the intervention of product category in the private label purchase decision

\section{Research Design and Methodology}

The study has been designed as a cross sectional descriptive study. Since a readymade questionnaire was not available on the subject, the questionnaire was prepared through literature by identifying major parameters of consumer attitude and perception being considered for private labels. The perception of private labels as compared to national brands was measured on a five point Likert scale; 1 for strongly disagree and 5 for strongly agree. While designing the survey questionnaire, it was observed that people were not aware about definition of private label brand. To avoid any misinterpretation a brief description of private label brands was introduced in the beginning of the survey. The respondents, who do not visit/purchase from modern retail stores, were filtered 
at the first question from the responses. 171 responses were considered out of 227 responses received. The questionnaire was administered amongst working executives in private and government organizations in the NCR of Delhi. The questionnaire design considered two dimensions;

i. Demographics of the respondent such as gender, age, occupation and personal income (Tables 1-4)

ii. Perception of respondents towards private labels in comparison to national brands on ten psychographic variables as mentioned in Table 5 below.

Table 1 Demographic Composition of the Sample Data: Gender

\begin{tabular}{|l|l|l|}
\hline Gender & Frequency & \multicolumn{1}{c|}{ Percent } \\
\hline Female & 69 & 40.4 \\
\hline Male & 102 & 59.6 \\
\hline Total & 171 & 100.0 \\
\hline
\end{tabular}

Table 2 Demographic Composition of the Sample Data: Age Group

\begin{tabular}{|c|c|c|}
\hline Age Group & Frequency & Percent \\
\hline $20-25$ & 26 & 15.2 \\
\hline $26-30$ & 53 & 31.0 \\
\hline $31-35$ & 34 & 19.9 \\
\hline $36-40$ & 20 & 11.7 \\
\hline $41-50$ & 18 & 10.5 \\
\hline 51 and above & 20 & 11.7 \\
\hline Total & 171 & 100.0 \\
\hline
\end{tabular}

Table 3 Demographic Composition of the Sample Data: Income Group

\begin{tabular}{|l|l|l|}
\hline \multicolumn{1}{|c|}{ Income Group } & \multicolumn{1}{c|}{ Frequency } & \multicolumn{1}{c|}{ Percent } \\
\hline Below 100000 & 10 & 5.8 \\
\hline $100000-250000$ & 27 & 15.8 \\
\hline $251000-500000$ & 30 & 17.5 \\
\hline $500001-1000000$ & 46 & 26.9 \\
\hline 1000001 and Above & 58 & 33.9 \\
\hline Total & 171 & 100.0 \\
\hline
\end{tabular}


Table 4 Demographic Composition of the Sample Data: Occupation

\begin{tabular}{|l|l|l|}
\hline Occupation & Frequency & Percent \\
\hline Salaried & 105 & 61.4 \\
\hline Self Employed & 23 & 13.5 \\
\hline Student & 14 & 8.2 \\
\hline Home maker & 29 & 17.0 \\
\hline Total & 171 & 100.0 \\
\hline
\end{tabular}

Table 5 Consumer Psychographic Motivations Defined

\begin{tabular}{|l|l|}
\hline $\begin{array}{c}\text { Consumer } \\
\text { Psychographic } \\
\text { Motivations }\end{array}$ & \multicolumn{1}{|c|}{ Definitions } \\
\hline Quality & $\begin{array}{l}\text { Product quality of private labels in comparison to } \\
\text { national label brands }\end{array}$ \\
\hline $\begin{array}{l}\text { Price } \\
\text { consciousness }\end{array}$ & $\begin{array}{l}\text { Price of private labels in comparison to available } \\
\text { substitute/ equivalent products in national brands }\end{array}$ \\
\hline Pack size & $\begin{array}{l}\text { Availability of convenient pack size of product in } \\
\text { private label in comparison to national brands }\end{array}$ \\
\hline Variety & $\begin{array}{l}\text { Availability of variety of private label products in } \\
\text { comparison to national brands }\end{array}$ \\
\hline Packaging & $\begin{array}{l}\text { Attractiveness of product packaging of private labels } \\
\text { in comparison to national brands }\end{array}$ \\
\hline Need Satisfier & $\begin{array}{l}\text { Product orientation to fulfill consumer need - } \\
\text { Private labels products in comparison to national } \\
\text { brands }\end{array}$ \\
\hline $\begin{array}{l}\text { Discount } \\
\text { /Promotion }\end{array}$ & $\begin{array}{l}\text { In terms of providing promotional benefits such as } \\
\text { discount/ extra quantity/ freebies / coupons etc. - } \\
\text { private labels in comparison to national brands }\end{array}$ \\
\hline $\begin{array}{l}\text { Pre-sales } \\
\text { Counseling }\end{array}$ & $\begin{array}{l}\text { In terms of getting pre-sales information (quality, } \\
\text { offers, features etc.) from store executive for private } \\
\text { labels in comparison to national brands }\end{array}$ \\
\hline $\begin{array}{l}\text { After Sales } \\
\text { Support }\end{array}$ & $\begin{array}{l}\text { In terms of getting after-sales support (exchange, } \\
\text { return, warrantee etc.) for private labels in } \\
\text { comparison to national brands }\end{array}$ \\
\hline $\begin{array}{l}\text { Credibility } \\
\text { associated } \\
\text { with } \\
\text { store name } \\
\text { retail }\end{array}$ & $\begin{array}{l}\text { How strongly retail store leverage their store brand } \\
\text { goodwill associated with private labels in } \\
\text { comparison to national brands. }\end{array}$ \\
\hline
\end{tabular}




\begin{tabular}{|c|c|}
\hline Cronbach's Alpha & N of Items \\
\hline .861 & 20 \\
\hline
\end{tabular}

The Cranach's Alpha value for the questionnaire responses is higher than 0.8 , which suggest that the data is internally consistent

\section{Factor Analysis}

The collected data from the questionnaires were filtered out for missing values, duplication and other anomalies, finally 171 data points were used for the analysis. Based on the value of the KaiserMeyer-Olkin Measure of Sampling Adequacy $(\mathrm{KMO}=0.706)$ and high chi-square value of the Bartlett's test of Sphericity (Chi-sq = 432 with degree of freedom $=45$ ), which shows the degree of common variance among the variables is quite high, Factor analysis technique is undertaken to explain the covariance relationships among the motivational reasons for purchase of private labels. This in turn, describes the covariance relationship in terms of few underlying, but unobservable random quantities called Factors. However, the factor analysis is guided by the following argument that motivational reasons can be grouped by their correlations. That is, all motivational reasons within a particular group are highly correlated among themselves but have relatively smaller correlations with motivational reasons in a different group. In consequence, it is conceivable that each group of motivational reasons represents a single unobserved random variable named as factor, which is responsible for the observed correlation among the motivational reasons. Mathematically factor model of $p$ motivational reasons and $\mathrm{m}$ common factors is represented in matrix notation as;

$$
\mathbf{X}_{(p x 1)}=\boldsymbol{\mu}_{(p x 1)}+\mathbf{L}_{(p x m)} \mathbf{F}_{(m x 1)}+\boldsymbol{\varepsilon}_{(p x 1)}
$$

where,

$\mu_{i}=$ mean score of ith motivational reasons,

$\varepsilon_{i}=i^{\text {th }}$ specific factor,

$F_{j}=j$ th common factor,

$l_{i j}=$ loading of the $i^{\text {th }}$ motivational reasons on the $j^{\text {th }}$ factor

and

$E(\mathbf{F})=\mathbf{0}, E(\boldsymbol{\varepsilon})=\mathbf{0}, \operatorname{Cov}(\mathbf{F}, \boldsymbol{\varepsilon})=\mathbf{0}$,

$\operatorname{COV}(\mathbf{F})=\mathbf{I}, \operatorname{COV}(\boldsymbol{\varepsilon})=\boldsymbol{\psi}$, where $\boldsymbol{\psi}$ is the diagonal matrix 
The factor loading $\mathrm{l}_{\mathrm{ij}}$ are estimated by the popular estimation procedure, principal component method. In order to summarize the information contained in the original $\mathrm{p}$ variables, $\mathrm{m}$ number of factors is extracted.

Table 7: KMO and Bartlett's Test

\begin{tabular}{|l|l|r|}
\hline \multicolumn{2}{|c|}{ Kaiser-Meyer-Olkin Measure of Sampling Adequacy. } & .706 \\
\hline \multirow{2}{*}{ Bartlett's Test of } & Approx. Chi-Square & 431.869 \\
\cline { 2 - 3 } & df & 45 \\
\cline { 2 - 3 } & Sig. & .000 \\
\hline
\end{tabular}

Initially private label motivations were evaluated through $\mathrm{p}=10$ original variables such as "Better in terms of product quality than National Brands", or "Comparatively cheaper for equivalent/substitute product than National Brands" etc. In the absence of any prior information, the number of factors $(\mathrm{m})$ is estimated through evaluation of following facts. The Scree plot, which is nothing but a plot between number of eigen values and factor of motivational reasons in order of extraction, has distinct break point between the steep slope of factors and a gradual trailing off associated with rest of the factors. This gradual trailing off points indicated the possible number of factors and it is observed to be three in this analysis (Figure 1). At the same time the eigen values of these factors are greater than one whereas other factors has less than one, which again indicate the extracted number of factors should be six. Thus, three factors of motivational reasons are extracted, which explains 61.09 per cent of the total variability, named as value for money, supplemental benefits and quality. To enhance the interpretation, these extracted factors were orthogonally rotated by varimax procedure with Kaiser Normalization. 


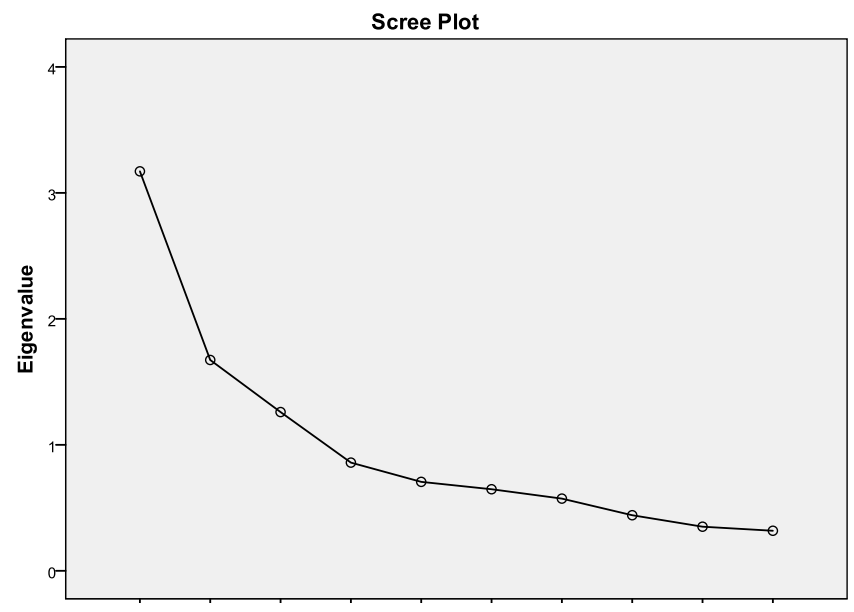

Fig. 1 Scree Plot for Customer Motivations

\section{Supplemental Benefits}

The first factor Supplemental benefits accounted for $23.41 \%$ of variance. It consisted of pre and post sales services, measured through items such as pre-sales counselling available with private labels as compared to national brands with a factor loading of 0.698 and after sales support in terms of exchange, service and warranty available with private labels as compared to national brands with a factor loading of 0.856 . The brand credibility also played an important role with a factor loading of 0.784

\section{Value for Money}

The value for money factor accounted for $21.97 \%$ of the total variance. It consisted of two variable of Price Consciousness with a factor loading of 0.897 and Discount/Freebies with a factor loading of 0.785 .

\section{Product Features}

The third factor comprised of Quality 0.787, Pack Size 0.544, Variety 0.731, Packaging 0.608 and Need Satisfier 0.566. The product features factor contributed to $15.66 \%$ of variance. 
The literature justifies value for money as the significant motivator for private labels but the results indicate that pre and post benefits in terms of counselling and after sales support and private label credibility also play an important role in the private label purchase decision as clubbed in the factor supplemental benefits and product features also play an important role. At this point it becomes important to map their direction with the product category and see if there is any association. This leads to the next level of analysis in the form of correlation analysis. This may only give us insight into movement of the variables but in case an association is observed then retailers will have to include it in their sales approach.

\section{Correlation Analysis}

Pearson product-moment correlation coefficient, or "Pearson's correlation coefficient", is the most common measure of dependence between two quantities called simply "the correlation coefficient". It is obtained by dividing the covariance of the two variables by the product of their standard deviations. The Pearson correlation is +1 in the case of a perfect positive (increasing) linear relationship (correlation), -1 in the case of a perfect decreasing (negative) linear relationship (anti-correlation) and some value between -1 and 1 in all other cases, indicating the degree of linear dependence between the variables. As it approaches zero there is less of a relationship (closer to uncorrelated). The closer the coefficient is to either -1 or 1 , the stronger the correlation between the variables. If the variables are independent, Pearson's correlation coefficient is 0 , but the converse is not true because the correlation coefficient detects only linear dependencies between two variables. The SPSS package gives the associated significance values with the correlation values as $\mathrm{p}$ values at a specified confidence interval. For this study the confidence interval level is taken at $95 \%$.

The three factors as identified in the previous stage; supplemental benefits, value for money and product features scores are saved as three variables and they are correlated with the scores on customers product category private label purchases again on a Likert scale of 1-5, strongly disagree - strongly agree. The ten product categories considered for the study are; 
1. Staple Food (Food/Grain/Flour/Spices/Pulses)

2. Biscuits \& Chocolates

3. Snack/Savory Items

4. Noodles/Pasta/Porridge/Vermicelli

5. Sauce/ketchup/Jam/Honey

6. Soap/ tooth paste/skin cream

7. Household Cleaning Products(Detergent/Powder/Floor/Glass Cleaner)

8. Consumer Durable (Mixer/Juicer/grinder)

9. Highend Durables(Washing Machine, Refrigerator, AC)

10. Electronics (TV/DVD/Play Station)

Table 8 shows the $p$ value at $95 \%$ confidence intervals which were significant;

Table 8 Significant Correlations between Product Category and Private Label Motivator

\begin{tabular}{|c|c|c|c|c|}
\hline & & 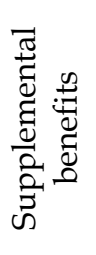 & 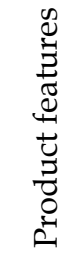 & 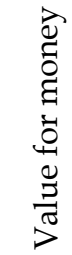 \\
\hline $\begin{array}{l}\text { Staple Food (Food/Grain/ } \\
\text { Flour/Spices/Pulses) }\end{array}$ & Sig. (2-tailed) & - & - & .002 \\
\hline Biscuits \& Chocolates & Sig. (2-tailed) & .000 & - & - \\
\hline Snack/Savory Items & Sig. (2-tailed) & .000 & - & - \\
\hline $\begin{array}{l}\text { Noodles/Pasta/ } \\
\text { Porridge/Vermicelli }\end{array}$ & Sig. (2-tailed) & .000 & .005 & - \\
\hline $\begin{array}{l}\text { Sauce/ketchup/ } \\
\text { Jam/Honey }\end{array}$ & Sig. (2-tailed) & .000 & .004 & - \\
\hline $\begin{array}{l}\text { Soap/ tooth paste/ } \\
\text { skin cream }\end{array}$ & Sig. (2-tailed) & - & .000 & - \\
\hline $\begin{array}{l}\text { Household Cleaning } \\
\text { Products(Detergent/ } \\
\text { Powder/Floor/Glass Cleaner) }\end{array}$ & Sig. (2-tailed) & .001 & .017 & .004 \\
\hline $\begin{array}{l}\text { Consumer Durable } \\
\text { (Mixer/Juicer/grinder) }\end{array}$ & Sig. (2-tailed) & .000 & .000 & - \\
\hline $\begin{array}{l}\text { High end Durables(Washing } \\
\text { Machine, Refrigerator, AC) }\end{array}$ & Sig. (2-tailed) & .000 & .000 & .003 \\
\hline $\begin{array}{l}\text { Electronics (TV/DVD/Play } \\
\text { Station) }\end{array}$ & Sig. (2-tailed) & .000 & .001 & - \\
\hline
\end{tabular}


As seen from Table 8 the significance of private label motivator varies across product category. For staple food, household cleaning products and high end durables price in terms of value for money is an important private label motivator, along with product features and supplemental benefits for the latter two. For staple food only value for money is significant. For consumer durables, electronics and noodles and sauce category supplemental benefits and product features are important whereas price is not. There is a possibility that for electronics and consumer durables it would be all three items within the factor that are important i.e. pre and post selling activities with brand reputation whereas for noodles and sauces category it could be brand in the supplemental benefits along with product features. This could be an important insight for category management for the Indian retail marketplace and needs to be validated. For biscuits and chocolates it seems only supplemental benefits (brand) is significant whereas for cosmetics category that includes soap, toothpaste and skin cream only product features are important.

\section{Interpretation of the Results}

The findings of the study corroborate the fact that urban Indian consumers typically buy private labels that offer them supplemental benefits in terms of pre purchase and post purchase activities along with brand implication, differentiate in product features and also look for price as the value in them across their private label purchases as evidenced by the factor analysis. However, the nature of the product category is an important variable and there could be a difference on private label purchase motivations across product categories. The reason for this is the level of involvement that the customer has with that particular product category. The level of involvement in buying decisions varies, starting from decisions that are fairly routine to decisions that require extensive thought and a high level of involvement. Low-involvement decisions products are relatively inexpensive and pose a low risk to the buyer if she makes a mistake by purchasing them, i.e. the functional and financial risk is very low. However with high involvement products the functional and financial risk is high and this makes branding very relevant to 
them. Brands give customer a promise on these aspects and he/she is much more assured of when buying this product. Even in low cost items, brands play an important role in assuring the customer of distinctiveness and quality. Thus products which are generic in nature and brands really do not differentiate are the ones where value for money play is an important motivator for private labels. However, product categories where customer involvement is relatively higher in terms of brand association and product features, even if the unit price is low, supplemental benefits and product features play an important motivation role for inducing customer purchase. Thus retailers have to look for branding, value added benefits and product features within different product categories with respect to their private label strategy.

\section{Managerial Implications}

The findings of the study explicitly bring out the following that the Indian retail managers need to take care about;

i. Customers have different motivations to buy private labels and they need to profiled and mapped to their motivations so that the retailer's marketing strategy is directed and focused on these to achieve customer satisfaction

ii. The nature of product and level of customer involvement with that product is to be clearly understood by the retailers as there is a difference in the reasons to buy private labels across product categories

iii. Retailers need to understand the importance of branding as applied to their private labels and the association that it brings to the product to overcome customer resistance.

\section{Conclusion}

Private labels are the next bet for growth in the Indian retail industry. Retailers need to proactively accept and bring forth this in their strategies as competition increases in the sector. The study findings set the stage for the findings to be validated across industry so that action is taken in real time. 


\section{References}

Burton, S., Donald, R., \& Judith. (1998). A scale of measuring attitude towards private label products and examination of psychology and behavioral correlates. Journal of the Academy of Marketing Science, 26 (4), 293-306.

Gala, D., Ramachandra, \& Patil, D. (2013). Consumer attitude towards private label in comparision to national brands. International Journal of Business and Management Invention , 2 (5), 12-18.

Koschate, F. N., Cramer, J., Hoyer, \& Wayne, D. (2014). Moderating effects of relationship between private label share and store loyalty. Journal of Marketing , 78 (2), 69-83.

Richardsoii, Paul, S., Dick, A. S., \& Jain, A. K. (1994). Exterinsic and interinsic cue effects on perceptions of store brand quality. Journal of Marketing , 58, 28-36.

Scattone, J. (1997). Consumers evaluation of private brands: The moderating influence of attitude strength on persuasion. United States: UMI Microform.

Selvakumar, J., \& Varadharajan, P. (2013). Study on the growth prospects of private labels to that of national brands in the FMCG retail sector in Coimbatore. International Journal of Economics , Business and Finance , 1 (2), 26-34.

Senthilvel, K. K., \& Jawahar, D. P. (2013). Building private labels into strong brands. IUP Journal of Brand , 10 (2), 42.

Sestokaite, A. (2010). Consumers orientation towards private labels and national brands in different product catagories-Exploring young adults personal values through means-end-chain analysis. Aahrus School of Business, Department of Marketing and Statistics. Aahrus: University of Aahrus .

Shukla, P., Banerjee, M., \& Adidam, P. T. (2013). The moderating influence of socio-demographic factors on the relationship between consumers psycographics and attitude towards private label brands. Journal of Consumer Behaviour , 12 (6), 423-435. 